\title{
Utilization Clonal Selection Program to Improve Resistance Garlic (Allium sativum L.) Against Onion Maggot (Delia antiqua M.)
}

\author{
Entsar Ibrahem Masaud Raghe ${ }^{1 *}$ and Amany Moustafa Hassan Abu-shall ${ }^{2}$ \\ ${ }^{1}$ Vegetable Dep., Faculty of Agriculture, Alexandria University, Egypt, ${ }^{2}$ Applied Entomology and Zoology Dep., \\ Faculty of Agriculture, Alexandria University, Egypt. \\ * Corresponding author: dr.entsar2110@gmail.com
}

Received on: 17-4-2021

Accepted on: 21-5-2021

\begin{abstract}
Onion maggot (Delia antiqua $\mathrm{M}$ ) is an economically important pest of Allium crops throughout the world; thus, management of this pest is required to achieve economic returns. Accordingly, this study aimed to select some clones of garlic resistant to infestation with onion magg ot through the implementation three cycles of clonal selection program within some improved garlic clones derived fromBalady cultivar. Afterwards, the developed clones and their original population were evaluated in a randomized complete block design with three replicates. Thus, this study was conducted during four successive winter seasons of 2016/2017 to 2019/2020. The obtained results showed, clearly, significant differences among garlic selected clones, as well as their original population in their response to Delia antiqua M. and their bulb characteristics. Where, the selected clones varied between resistant and ability of infestation by onion maggot that was between $0.00 \%$ and $22.45 \%$, with clas sification into five groups by clus ter analysis: HR (highly resistant), R (resistant), MR (moderately resistant), MS (moderately susceptible) and S (susceptible). Among the 16 selected clones three clones were HR; and six clones were R to onion maggot. Moreover, improvement percentage for the same character using clonal selection program was between $48.97 \%$ to $100 \%$, which reflected that clonal selection could be an effective way to impro ve onion maggot resistance. Also, utilization of these improved clones will promise in minimize environmental pollution.
\end{abstract}

KEYWORDS: Garlic, selection, cluster, resistance, Onion maggot, Delia antiqua.

\section{INTRODUCTION}

Garlic (Allium sativa L.) is the second most important bulb crop after onion belonging to family Alliaceae and genus Allium; which, has more than 600 available species. Also, considered one of the most important vegetable in Egypt; that, grown for both exportation and local consumption; as green fresh, semi-dry, dry, or processed products.

Garlic is attacked by several insect pests and diseases; and onion maggot is considered one of the most pests; which attack garlic plants at different phases. Onion maggot, Delia antiqua (Meigen, 1826) (Diptera: Anthomyiidae), is an oligophagous insect specializing on crops of genus Allium and could be considered a key pest of Alliaceous crops in many parts of the world. This pest feed on numbers of Alliaceous plants including onion, garlic and leeks and caused yield losses ranging about $20-60 \%$ (Hermize 2012, Taylor et. al. 2000). There are three generations of onion maggot each year (Eckenrode et. al. 1975); but the first-generation is the most damaging (Liu et. al. 1982, Loosjes 1976). Females are typically deposited in batches of two to four eggs per plant (Mowry 1993). The larvae are developing through three instars in two to three weeks and later pupating in the soil (Hoffman et. al. 1996). Hatching larva feed internally or externally on the garlic stem that underground or after bulb formation. Larvae feed and makes burrow inside bulbs leading to wilting and dead cloves; and one larva may feed many cloves before its pupation (Klass and Snover 2000). Besides, feeding sites and the wounds that caused by larva led to easy hit in cloves or bulb by bacteria and fungi. Accordingly, onion maggot insect causes undesirable effects during harvesting, post harvesting, processing and marketing stages; which, effect negatively on cropping pattern, quality and export potential of the crop and then local and export markets affect; so, cause clearly economic loss.

Pesticides is considered as the main control procedures for the onion maggot; where it can be applied as seed treatment or foliar application, which may led to appearance of insecticide resistance; in 
another words, insect control has become challenging due to insecticide resistance (Nault et. al. 2006). On another side, there are very limited effective and practical non-chemical procedures for control of onion maggot. For example, trap cropping has been considered in the past as a primitive method of onion maggot control(Mowry 1993). Natural enemies, also, considered one of non-chemical methods that may play a role in preventive of onion maggot (Hoffmann et. al. 1996). Cultural practices have been advanced for onion maggot; but do not play a tangible role in its control. Therefore, it is very important exploiting the presence of the pest-resistance genes of plants; where, plant resistance has been investigated as a way of reducing onion maggot damage. Since, the use of resistant cultivars is an important and complementary management tool to deal with pest or any disease (Didelot 2016 and Vieira et. al. 2011). So, selection breeding program of resistant garlic cultivars could be very promising method that aimed to find alternative control system safe to humans, environment, and natural enemies.

A few resistant garlic cultivars against onion maggot have been selected out of the previous studies (Wang et. al. 2010). Garlic is a typical vegetative propagated crop, due to its sexual sterility; thus, clonal selection is a major breeding method for this crop.

Despite the importance of this crop, very limited breeding work has been done so far in this respect. Thus, this study is a part of a complementary breeding program to improve the garlic crop; where, this study focuses on applying a clonal selection program to garlic, Balady cultivar, in order to create insect-resistant clones, thereby increasing the storage ability of the crop while maintaining bulb quality and productivity.

\section{MATERIALS AND METHODS}

\subsection{Original Genetic Materials.}

A total 350 bulbs from improved different garlic clones were used in this study as the original population to start the clonal selection program. These clones were obtained by clonal selection program of Balady cultivar for seven years to improve yield and quality bulbs of garlic. This garlic breeding program was conducted, by the author, at Vegetable Crop department, Faculty of Agriculture, Alexandria University. So, this program considered a part of a comprehensive study aimed to obtain new garlic clones' resistance to onion maggot with good yield and quality.

\subsection{Examination of Onion Maggot Damage Levels of Garlic Bulbs in the Original Population.}

During all selection cycles of this study; the bulbs of garlic were cleaned and split into individual clove per each garlic bulb. Different bulbs of each clone, which infested by onion maggot were investigated in lab under binocular. Onion maggot damage of garlic bulbs was estimated by the numbers of larvae and the area of damage that the larvae fed upon. Percentages of onion maggot infestation were calculated in all garlic bulbs of each clone upon (Fig.1).
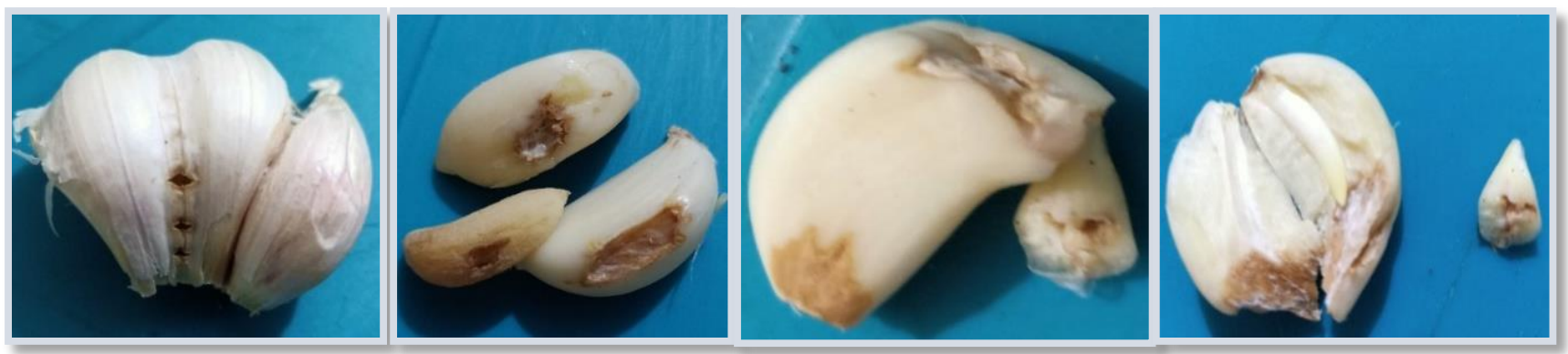

Fig 1 . The symptoms of the infestation by onion maggot, Delia antiqua on the garlic cloves

\subsection{Experimental Work and Breeding Program.}

The present study was carried out during three successive winter seasons of 2017/2018, 2018/2019 and 2019/2020 at the Experimental Station Farm, Faculty of Agriculture, Alexandria University; at Abies, Alex, A.R.E.

This program was started in 2017/2018, at 1 Sept. by checkup the 350 bulbs before seedling with
20 days, which considered the first cycle of clonal selection in this study. The garlic bulbs were manually split into individual cloves so as not damage the outer peel and injured bulbs were ruled out after inspection it as previously mentioned. According to the initial selection, the best 100 selected bulbs; on the basis of healthy and free of onion maggot damage bulbs with heavier bulb weight and less cloves number per bulb; were planted separately, that mean each bulb in a 


\section{Scientific Journal of Agricultural Sciences 3 (1): 38-45, 2021}

separate line. The cloves were hand planted on both sides of the line at approximately $7 \mathrm{~cm}$ apart within each row and $60 \mathrm{~cm}$ wide. The planting dates were 21 Sept. in the three successive winter seasons of 2017/2018, 2018/2019 and 2019/2020. No insecticide was applied during the all-growing seasons; while all manual loosing and weeding were carried out during the vegetation. Harvesting was carried out on the 15 Apr. of the three consecutive seasons; and garlic bulbs of each clones were finally drying in well-ventilated storage area.

In the second season, the second cycle of clonal selection started; where, health statues of each clone were assessed visually from the end of June at regular weekly intervals; when, visible symptoms of damage were noticed, the bulb was removed from the clone, with registered number of bulbs that excluding from each clone. Before cultivation with 20 days; the pest resistance bulbs from each clone, 100 clones, selected as previously mentioned. Accordingly, the best 50 selected clones from the 100 were planted separately as described earlier in the first season, as well as, at harvest period the same selection procedures were practices in the second season; that considered the third cycle of clonal selection, to obtain the most promising selected clones; which came out to be 16 clones.

\subsection{Adult Activity of $D$. antiqua Within Garlic Field.}

At different spots of field, four yellow sticky cards $(15 \mathrm{~cm} \times 15 \mathrm{~cm})$ were placed facing into the field on the edge of the field. Where, sticky cards are the standard trapping method used to scout Delia populations and Delia antiqua is more attracted to yellow traps, rather than blue ones (Mlynarek et. al. 2020). The sticky cards were clamped to stakes at height of $15 \mathrm{~cm}$ above the soil. Thereafter, height was adjusted to keep card tops level with the garlic canopy. These sticky cards were changed a weekly from the estimated start of first-generation fly emergence until harvest time in each season. Once these sticky cards were collected, they were returned to the laboratory. Delia species from the sticky traps were identified using the key provided by Savage et. al. 2016. A few specimens were removed from traps, mounted Delia spp. at the sticky cards as vouchers to infestation with this specie of insects. Only males were identified because females of Delia spp. cannot be reliably distinguished morphologically, especially from sticky cards. Additionally, identific ation of female Delia spp. relies on the number and position of bristles on the legs and thorax, which can be lost or damaged on sticky cards, leading to misidentifications (Mlynarek et. al. 2020). The number of onion maggot flies captured per sticky card within garlic fields was counted. These data enabled us to relate incidence of plant damage to female onion maggot phenology.

\subsection{Evaluation of the Various Genetic Populations.}

In the winter season of 2019/2020, healthy cloves from the 16 selected clones, which reflected high stability during successive seasons for the resistance trait, as well as sample of cloves from the original population, Balady cultivar, were planted on 21 Sept. 2019/2020 in a Randomized Complete Block Design. Three plots were used as replicates for every genotype and the genotypes were randomly distributed in the field. The experimental plot was consisted of 2 row s, $3 \mathrm{~m}$ long and $0.6 \mathrm{~m}$ width and cloves were hand planted approximately $7 \mathrm{~cm}$ apart on the two sides of ridge. All the recommended cultural practices were applied during the growing season; with the exception of the pesticides application that were not added during the season. After harvesting, the plants of each clone were left for curing for about 15 days and then stored at the storge room. Data of bulb characteristics were taken at the same time during the all studying seasons; after curing process; while, examination of bulbs to onion maggot infestation was recorded at 1 Sept. A random sample of five plants from each genotype were collected from each plot to measure and estimate the following parameters:

1- Bulb wight (g): the average cured bulb weight of five plants was recorded in grams.

2- Bulb diameter $(\mathbf{c m})$ : the cured bulb diameter was recorded using a caliper.

3- Cloves number per bulb: cloves of each bulb were counted and the average of Cloves number from five bulbs was estimated.

4- Onion maggot infestation \%: number of infested cloves in each sample total number of cloves

X 100

5- Resistance improvement \%:

infestation in original population - infestation in clone

infestation in original population

X 100

\subsection{Statistical Analysis.}

The mean values of each character under the study were computed and subjected to analysis of variance, following the procedures described by AlRawi and Khalf-Allah (1980), using Co-Stat computer software program (2004). The collected data were analyzed using SPSS (version 24) and Squared Euclidean distance, which was used as a measure of distance for cluster formation. 
Entsar Ibrahem Masaud Ragheb and Amany Mostafa Hassan Abu-shall., 2021

\section{RESULTS AND DISCUSSION}

\subsection{Performance of Different Garlic Genotypes Against Onion Maggot, Delia antiqua Infestation and Some Important Bulb Characteristics.}

Performance of different selected clones and their original population of garlic against onion maggot population and yield contributing characters are presented in Table (1). The differences among the genotypes were significant for all studied parameters. Among the different clones, clone 8 and 13 did not reflect any percentage of onion maggot infestation as compared to rest of the selected clones as well as the original population. Whereases, the lowest infestation percentages with $D$. antiqua were recorded from the garlic clones 8, 13 and 7, (0.00, 0.00 and 1.65\%) respectively; moreover, there were insignificant differences among these three clones. On the other hand, the highest infestation percentage with $D$. antiqua for all genotypes was reflected by the original population (Balady cultive). While the highest infestation percentage among the selected clones was recorded from clone 1 (22. 45\%); preceded by the clone 10 and clone 3 , respectively, with significant differences between clone 1 and the other two clones 10 and 3 . These results clarified that the three improved clones number 8, 13 and 7 reflected highly resistance to $D$. antiqua and could be selected as a unclose for the new cultivar in the breeding program.

Concerning the three bulb characteristics; bulb diameter, bulb weight and cloves number per bulb; the result illustrated that significantly the maximum bulb diameter $(6.49 \mathrm{~cm})$ was recorded from the clone 13 followed by clone $16(6.25 \mathrm{~cm})$ and clone $4(6.22 \mathrm{~cm})$. While, the minimum bulb diameter $(4.01 \mathrm{~cm})$ was observed by Balady cultivar and the selected clone 10 $(5.31 \mathrm{~cm})$ with significant difference between them. The highest and significant average bulb weight was noticed in clone $7(51.34 \mathrm{~g})$ which was at par with clone $13(50.45 \mathrm{~g})$, followed by clone $16(47.63 \mathrm{~g})$ as compared to the rest clones, as well as the original population.

Table 1. Performances of different selected clones and their original population against Delia antiqua infestation and yield contributing characters of garlic.

\begin{tabular}{lcccc}
\hline Characters & $\begin{array}{c}\text { D. antiqua } \\
\text { Infestation } \\
\text { \% }\end{array}$ & $\begin{array}{c}\text { Bulb } \\
\text { diameter } \\
\text { (cm) }\end{array}$ & $\begin{array}{c}\text { Bulb } \\
\text { weight } \\
\text { (gm) }\end{array}$ & $\begin{array}{c}\text { Cloves number } \\
\text { per bulb }\end{array}$ \\
\hline Selected Clones & $22.45 \mathrm{~b}$ & $5.80 \mathrm{ef}$ & $39.53 \mathrm{ef}$ & $47.66 \mathrm{~b}$ \\
C 1 & $05.82 \mathrm{hi}$ & $5.91 \mathrm{de}$ & $38.00 \mathrm{fg}$ & $37.00 \mathrm{fg}$ \\
C 2 & $16.47 \mathrm{c}$ & $6.01 \mathrm{~cd}$ & $41.17 \mathrm{c}-\mathrm{e}$ & $35.33 \mathrm{gh}$ \\
C 3 & $07.21 \mathrm{gh}$ & $6.22 \mathrm{~b}$ & $40.69 \mathrm{~d}-\mathrm{e}$ & $41.33 \mathrm{~d}$ \\
C 4 & $10.43 \mathrm{ef}$ & $6.00 \mathrm{~cd}$ & $41.20 \mathrm{c}-\mathrm{e}$ & $36.33 \mathrm{f}-\mathrm{h}$ \\
C 5 & $09.98 \mathrm{fg}$ & $6.12 \mathrm{bc}$ & $31.43 \mathrm{ij}$ & $34.33 \mathrm{~h}$ \\
C 6 & $01.65 \mathrm{j}$ & $6.54 \mathrm{a}$ & $51.34 \mathrm{a}$ & $45.33 \mathrm{bc}$ \\
C 7 & $00.00 \mathrm{j}$ & $5.81 \mathrm{ef}$ & $43.33 \mathrm{c}$ & $37.00 \mathrm{fg}$ \\
C 8 & $07.15 \mathrm{gh}$ & $5.65 \mathrm{fg}$ & $35.72 \mathrm{gh}$ & $35.33 \mathrm{gh}$ \\
C 9 & $17.12 \mathrm{c}$ & $5.31 \mathrm{i}$ & $31.13 \mathrm{j}$ & $36.66 \mathrm{f}-\mathrm{h}$ \\
C 10 & $11.42 \mathrm{de}$ & $5.41 \mathrm{hi}$ & $33.55 \mathrm{hi}$ & $44.66 \mathrm{c}$ \\
C 11 & $12.90 \mathrm{~d}$ & $5.90 \mathrm{de}$ & $39.38 \mathrm{ef}$ & $38.66 \mathrm{ef}$ \\
C 12 & $00.00 \mathrm{j}$ & $6.49 \mathrm{a}$ & $50.45 \mathrm{a}$ & $39.66 \mathrm{de}$ \\
C 13 & $05.8 \mathrm{hi}$ & $5.88 \mathrm{de}$ & $42.56 \mathrm{~cd}$ & $44.66 \mathrm{c}$ \\
C 14 & $05.5 \mathrm{hi}$ & $5.51 \mathrm{gh}$ & $40.41 \mathrm{~d}-\mathrm{f}$ & $37.66 \mathrm{e}-\mathrm{g}$ \\
C 15 & $06.0 \mathrm{hi}$ & $6.25 \mathrm{~b}$ & $47.23 \mathrm{~b}$ & $36.33 \mathrm{f}-\mathrm{h}$ \\
C 16 & & & \\
Oroginal Pop. & $44.00 \mathrm{a}$ & $4.01 \mathrm{j}$ & $20.68 \mathrm{k}$ & $59.96 \mathrm{a}$ \\
Balady cultivar & & & \\
\hline
\end{tabular}

Values having the same alphabetical letter (s) within each column, don't significantly differ from one another, using Duncan's multiple range test at 0.05 level of significance. 
Concerning the cloves number per bulb, data on means comparison showed that there were, clearly, significant differences between Balady cultivar and the selected clones in desirable effect in toward lowest number of cloves. Where, it seems that number of cloves per bulb may be important trait and should be considered in breeding of local cultivar of garlic, Balady cultivar, that produced greater number of cloves with light weight, which considered unfavorable to Egyptian consumer. The highest number of cloves per bulb, undesirable effect, was given by Balady cultivar (59.96) with significant differences with the all-selected clones; while the lowest with mean $34.33,35.33$ and 35.33 cloves in the clones, 6, 3 and 9, respectively with insignificant differences. These results are confirmed with the conclusion of Al-Otayk et. al. 2008, Dawood et. al. 2011, and Omer and Abou-Hadid 1992; who stated that Balady cultivar recorded the lowest value of bulb weight and produced bulb with maximum number of cloves.

\subsection{Effect of Clonal Selection on Improvement of Resistance to Onion Maggot, Delia antiqua Infestation}

Improvement of resistance to Onion maggot infestation according to three clonal selection cycles of garlic was recorded in Fig 2. The calculated percentages of improvement stated that the two selected clones 8 and 13 were noticed to show the highest improvements for this character, compared to the all-selected clones and the original population; followed by the clone 7 . The improvement magnitudes of these three clones were estimated by $100 \%, 100 \%$ and $96.25 \%$, respectively, over the original population. Also, the six clones 14, 15, 16, 2, 9 and 4 reflected increments that estimated between $83.61 \%$ in clone 4 to 87.50 in clone 15 , relative to the original population. Some improvement was detected, also, in the case of the four clones 5, 6, 11, and 12; whose means reflected $76.29 \%, 77.31 \%, 74.04 \%$ and $70.68 \%$ improvements, respectively. While the lowest percentage of improvements were recorded by the clone 1 , preceded by the clones 10 and 3 with percentage as $48.97 \%, 61,09 \%$ and $62.56 \%$, respectively. From the previously mentioned result, in the present study, upon clonal selection from Balady cultivar, all selected clones reflected degree of resistance to Delia antiqua than their original population, showing an obvious effect of clonal selection; that could improve the resistance of garlic. The same results were given by Wang et. al. (2010 and 2019), when using clonal selection as breeding program to obtain resistance clones from garlic to Delia antiqua.

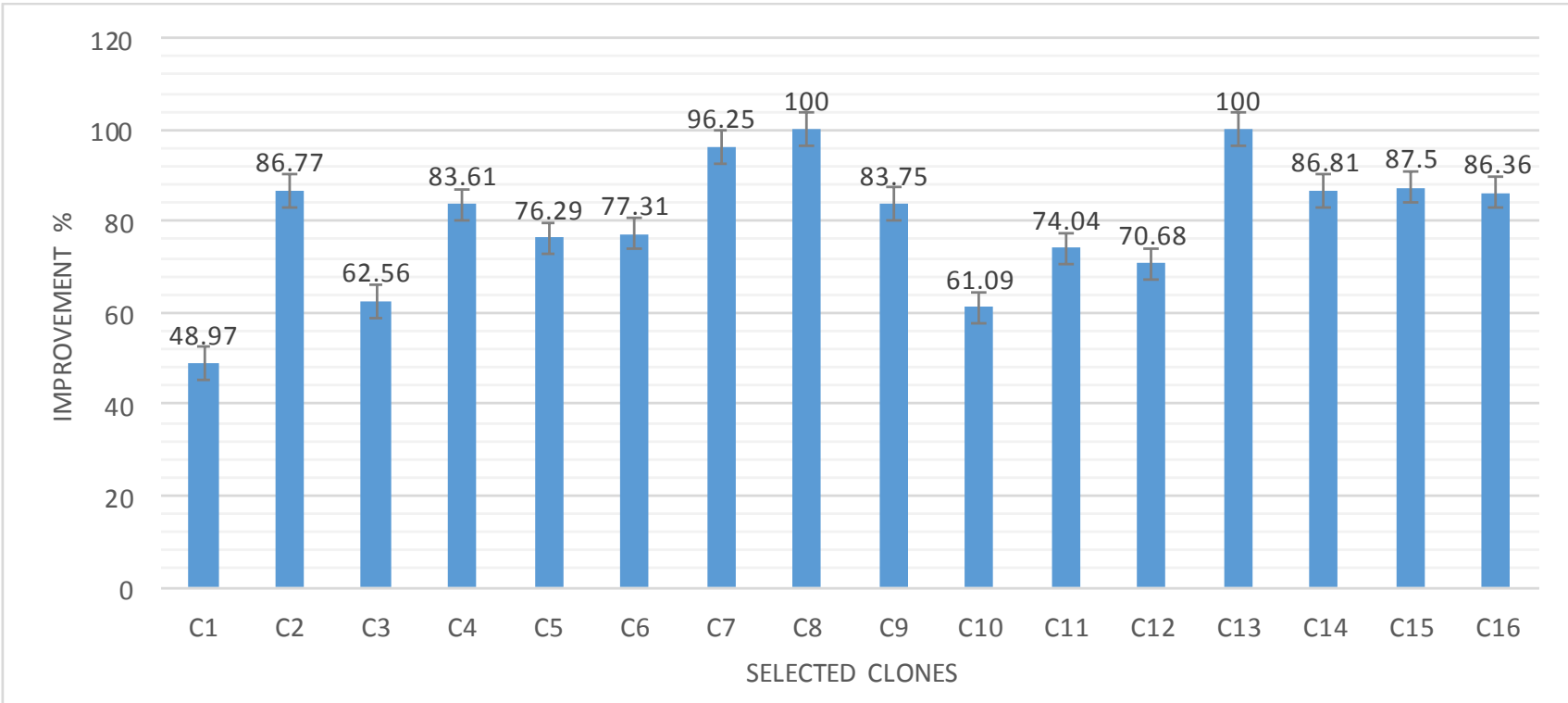

Fig. 2. Effect of clonal selection on resistance improvement to Onion maggot infestation 


\subsection{Classification of Garlic Clones for Their Resistance to $D$. antiqua Infestation.}

The different clones of garlic, selected from Balady cultivars, were grouped into five different categories of resistance viz., highly resistant, resistant, moderately resistant, moderately susceptible and susceptible: according to tree dendrogram and percentage of onion maggot infestation (Fig. 3 and Table, 2). The first cluster, which was highly resistant to onion maggot included three clones, corresponding to $18.75 \%$ of the total clones, with onion maggot infestation percentage ranging from $0-2 \%$ : clones 8 , 13 and 7 . The second cluster, which was resistant to onion maggot, included six clones corresponding to $37.50 \%$ of the total clones, with onion maggot infestation percentage from $3-8 \%$ : clones $4,9,2,14$, 16 and 15 . The third cluster, which was moderately resistant to onion maggot, included four clones, corresponding to $24.00 \%$ of the total clones, with onion maggot infestation percentage from $9-13 \%$ : clones $5,6,11$ and 12 . The fourth cluster, which was susceptible to onion maggot infestation, included two clones, corresponding to $12.50 \%$ of the total clones, with onion maggot infestation percentage ranging from $14-18 \%$ : clones, 3 and 10 .

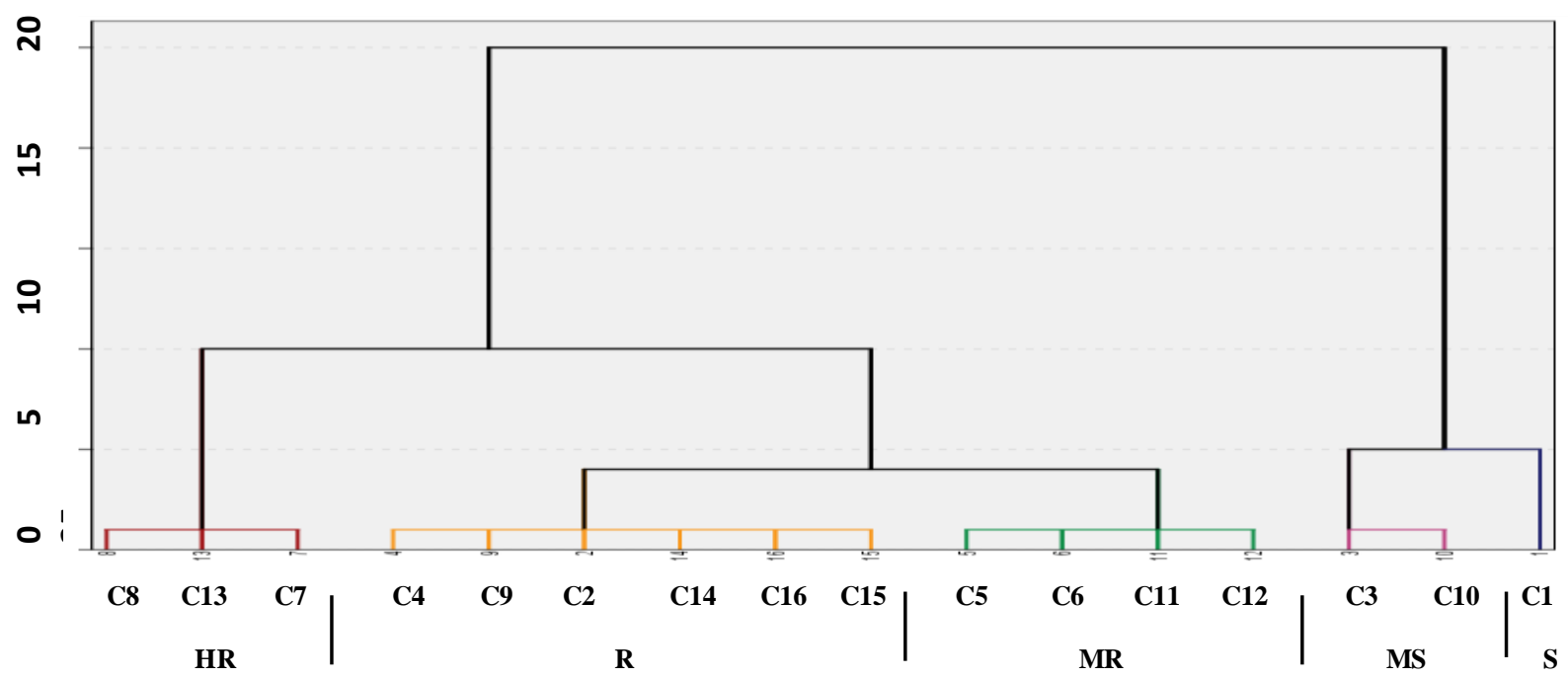

Fig.3. Tree dendrogram of onion maggot, Delia antiqua infestation values of 16 selected clones of garlic. HR, highly resistant to $D$. antiqua; $R$, resistant to $D$. antiqua; MR, moderately resistant to $D$. antiqua; MS, moderately susceptible to $D$. antiqua; $S$, susceptible to $D$. antiqua.

Keys: C1 - C16: selected clones

Table 2. Resistance distribution of the investigated 16 clones.

\begin{tabular}{cccc}
\hline Resistance group & $\begin{array}{c}\% \\
\text { onion maggot } \\
\text { infestation }\end{array}$ & $\begin{array}{c}\text { Number } \\
\text { of } \\
\text { Clones }\end{array}$ & $\begin{array}{c}\text { \% of each group to } \\
\text { total clones }\end{array}$ \\
\hline HR & $0-2$ & 3 & 18.75 \\
R & $3-8$ & 6 & 37.50 \\
MR & $9-13$ & 4 & 24.00 \\
MS & $14-18$ & 2 & 12.50 \\
S & More than 19 & 1 & 6.25 \\
\hline
\end{tabular}

HR, highly resistant to Deliaantiqua; R, resistant to D. antiqua; MR, moderately resistant to D. antiqua; MS, moderately susceptible to D. antiqua; S, susceptible to D. antiqua 
The fifth cluster, which was susceptible to onion maggot infestation, included one clone, corresponding to $6.25 \%$ of total clones, with onion maggot infestation percentage more than 19\%: clones 1. The obtained results were agreement with that reported by Wang et. al. 2019 who used cluster analysis to classify some accessions of garlic to onion maggot, Delia antiqua resistance into six group according to the pest index. So, cluster analysis based on morphological traits of genetic resources facilitate and help in breeding program with high efficiency, as shown in studies of the genetic resources of many crops (Saeed et. al. 2017, Singh and Jaiswal 2013,. Buso et. al. 2008, Matus et. al. 1999 and Ogwu et. al. 2018).

\section{CONCLUSION}

The findings of this study showed significant differences among selected clones as well as their original population for the studied bulb characteristics and their response to Delia antiqua. Where three clones were found to be highly resistant; in addition to 6 resistance clones. Therefore, these clones could be used in breeding programs to develop new cultivars that are resistant to onion maggot, $D$. antiqua. Utilization of such cultivars can reduce pollution of environment and biodiversity and make management procedures more economical. Thus, clonal selection activity could be an effective method to improve pest resistance and most of morphological and other important traits of garlic. Thus, could be using resistance clones with combinations of chemical, biological and cultural methods, and crop rotation as integrated pest management in garlic cultivation.

\section{REFERENCES}

Al-Rawi KM, Khalf-Allah AM (1980). Design and analysis of agriculture experiments. Text book. El Mousil Univ. Press. Ninawa, Iraq. 487 p.

Al-Otayk S, El-Shinawy MZ, Motawei MI (2008). Variation in productive characteristics and diversity assessment of garlic cultivars and lines using DNA markers. Met. Env. Arid Land Agric. Sci. 20: 63 - 79.

Buso GS, Paiva MR, Torres AC, Resende FV, Ferreira MA, Buso JA, Dusi AN (2008). Genetic diversity studies of Barazilian garlic cultivars and quality control of garlic-clover production. Genet. Mol. Res. 7(2): $534-541$.

Co-State Software (2004). User's manual version. Cohort Tusson, Arizona, USA.

Dawood AR, Abd-El Aal SA, Badawy AS, Attallah SY (2011). Testing of some garlic (Allium sativum L.) cultivars under Assiut conditions. Assiut J. Agric. Sci. 42 (2): $378-390$.

Didelot F (2016). Sustainable management of scab control through the integration of apple resistant cultivars in low-fungicide input system. Agr Ecosyst Environ. 217: $41-48$.

Eckenrode CJ, Vea EV, Stone KW (1975). Population trends of onion maggots correlated with air thermal unit accumulations. Environmental Entomology 4: 785-789.

Hermize FB (2012). Evaluation of some types of control methods against the Onion maggot, Delia alliaria Fonseca (Diptera: Anthomyiidae). Ph.D. thesis, College of Agriculture, University of Baghdad. Pp. 126.

Hoffmann MP, Petzoldt CH, Frodsham AC (1996). Integrated Pest Management for Onions. Cornell Cooperative Extension, NY, USA.

Klass C, Snover KL (2000). Onion maggot; Part 1: Pest management around he home, cultural method. Alternative Control Outreach Research Network (ACORN) at Purdue University. Cornell University.

Liu HJ, McEwen FL, Ritcey G (1982). Forecasting events in the life cycle of the onion maggot, Hylemya antiqua (Diptera: Anthomyiidae): Application to control schemes. Environmental Entomology 11: 751755 .

Loosjes M (1976). Ecology and Genetic Control of the Onion Fly, Delia antiqua (Meig.). Center for Agricultural Publishing and Documentation, Wageningen, The Netherlands.

Matus I, Gonzalez MI, Pozo AD (1999). Evaluation of phenotypic variation in a Chilean collection of garlic (Allium sativum L.) clones using multivariate analysis. Plant Genetic Resources Newsletter. 117: 31 $-36$.

Mynarek JJ, MacDonald M, Sim K, Hiltz K, McDonald MR, Blatt S (2020). Oviposition, Feeding Preferences and Distribution of Delia Species (Diptera: Anthomyiidae) in Eastern Canadian Onions. Insects, 11(780):1-10. DOI:10.3390/insects 11110780 Mowry, T M (1993). Ovipositional patterns and larval movement of Delia antiqua (Diptera: Anthomyiidae) on sprouted bulb and seedling onions. Journal of Economic Entomology 86: 1440-1445.

Nault BA, Straub AM, Taylor AG (2006). Performance of novel insecticide seed treatments for managing onion maggot (Diptera: Anthomyiidae) in onion fields. Crop Protections. 25: $58-65$.

Ogwu MC, Onosigbere-Ohwo U, Osawaru ME (2018). Morphological characterization of okra 
(Abelmoschus) accessions. Makara Journal of Science. 22(2): $67-76$.

Omer EA, Abou-Hadid AF (1992). Evaluation of some lines of Chinese garlic comparing with Balady cultivar. Egypt. J. Hort. 19: 17 - 20.

Saeed FJ, Farooq Mahmood A, Riaz M, Hussain T, Majeed A (2017). Assessment of genetic diversity for cotton leaf curl virus (CLCUD), fiber quality and some morphological traits using different statistical procedures in Gossypium hirsutum). Aust. J. Crop Sci. 8: $442-447$.

Savage J, Fortier AM, Fournier F, Bellavance V (2016). Identification of Delia pest species (Diptera: Anthomyiidae) in cultivated crucifers and other vegetable crops in Canada. Can. J. Arthropod Identif., 29: $1-40$.

Singh P, Jaiswal JP (2013). Assessment of genetic diversity in bread wheat (Triticum aestivum L. em Thell), genotypes based on agro-morphological traits using Mahalanobis D2 statistic. Environ Ecol. 31: 679 -682 .
Taylor AG, Eck enord CJ, Straub RW (2000). Seed coating technologies and Treatments for onion Challenges and Progress. New York State Agriculture Experiment Station. Cornell University, Geneva, NY 14456. Pp. 7.

Vieira SS, Bueno AF, Boff MI, Bueno RC, Hoffman-Campo CB (2011). Resistance of soybean genotypes to Bemisia tabaci (Genn) Biotype B (Hemiptera: Aleyrodidae). Neotrop Entomol. 40: 117 $-122$.

Wang HLi, Shen D, Yang Q, Song J (2010). Identification of resistance of Allium sativum L. germplasm resources to Delia antique M. J. Plant Genet. Resour. 11: 578 - 582.

Wang H, Wu Y, Liu X, Qu Z, Qiu Y, Song J, Zhang X, Li X (2019). Resistance and clonal selection among Allium sativum L. germplasm resources to Delia antiqua M. and its correlation with allicin content. Pest Management Science. 75: 2830 2839.

\section{الملخص العربي}

استخدام برنامج انتخاب السلالة الخضرية لتحسين مقاومة الثوم لابابة البصل (Delia antiqua M)

$$
\text { 'قسم الخضر ، كلية الزراعة، جامعة الاسكندرية - 'قشم الحشرات والحيوان التطبيقى، كلية الزراعة، جامعة الاسكندرية }
$$

نبابة البصل (Delia antiqua M) هي آفة مهمة اقتصاديًا لمحاصيل Allium في جميع أنحاء العالم ؛ وبالتالي ، فإن إدارة هذه

الآفة مطلوبة لتحقيق عوائد اقتصادية. وبناءً على ذلك ، فإن الهدف الرئيسي من هذه الدراسة هو انتخاب سلالات خضرية من محصول الثوم مقاومة لنبابة البصل من خلال تتفيذ ثلاث دورات من برنامج انتخاب السلالة الخضرية داخل مجموعة من سلالات الثوم المحسنة ، تلى ذلك تقييم السلالات المنتخبة وكذللك نباتات العشيرة الاصلية (الصنف البلدى) باستخدام تصميم القطاعات العشوائية الكاملة بثلاث مكرارات؛ وعليه فقد أجريت

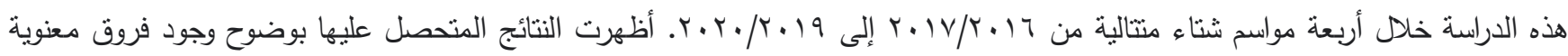
بين السلالات الخضرية المنتخبة من الثوم ، وكذلك العثيرة الاصلية في استجابتهم للبابة البصل . Delia antiqua M وكذلك مواصفات جودة

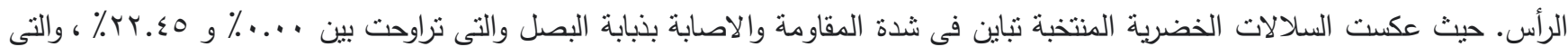

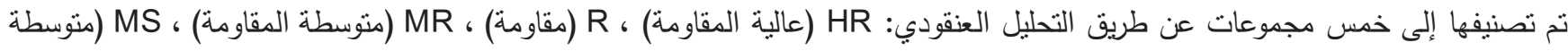

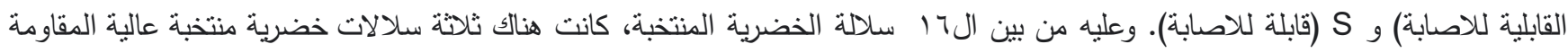
HR

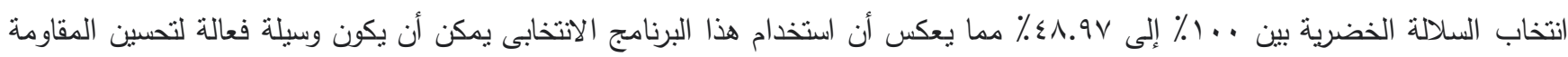
لذبابة البصل، أيضًا سبساعد استخدام هذه السلالات في تقليل التلوث البيئي. 